\title{
Psychometric evaluation of the Swedish version of the pure procrastination scale, the irrational procrastination scale, and the susceptibility to temptation scale in a clinical population
}

\author{
Alexander Rozental ${ }^{1 *}$, Erik Forsell ${ }^{2}$, Andreas Svensson $^{2}$, David Forsström ${ }^{1}$, Gerhard Andersson ${ }^{2,3}$ and Per Carlbring ${ }^{1}$
}

\begin{abstract}
Background: Procrastination is a prevalent self-regulatory failure associated with stress and anxiety, decreased well-being, and poorer performance in school as well as work. One-fifth of the adult population and half of the student population describe themselves as chronic and severe procrastinators. However, despite the fact that it can become a debilitating condition, valid and reliable self-report measures for assessing the occurrence and severity of procrastination are lacking, particularly for use in a clinical context. The current study explored the usefulness of the Swedish version of three Internet-administered self-report measures for evaluating procrastination; the Pure Procrastination Scale, the Irrational Procrastination Scale, and the Susceptibility to Temptation Scale, all having good psychometric properties in English.
\end{abstract}

Methods: In total, 710 participants were recruited for a clinical trial of Internet-based cognitive behavior therapy for procrastination. All of the participants completed the scales as well as self-report measures of depression, anxiety, and quality of life. Principal Component Analysis was performed to assess the factor validity of the scales, and internal consistency and correlations between the scales were also determined. Intraclass Correlation Coefficient, Minimal Detectable Change, and Standard Error of Measurement were calculated for the Irrational Procrastination Scale.

Results: The Swedish version of the scales have a similar factor structure as the English version, generated good internal consistencies, with Cronbach's a ranging between .76 to .87 , and were moderately to highly intercorrelated. The Irrational Procrastination Scale had an Intraclass Correlation Coefficient of .83, indicating excellent reliability. Furthermore, Standard Error of Measurement was 1.61, and Minimal Detectable Change was 4.47, suggesting that a change of almost five points on the scale is necessary to determine a reliable change in self-reported procrastination severity.

Conclusions: The current study revealed that the Pure Procrastination Scale, the Irrational Procrastination Scale, and the Susceptibility to Temptation Scale are both valid and reliable from a psychometric perspective, and that they might be used for assessing the occurrence and severity of procrastination via the Internet.

Trial registration: The current study is part of a clinical trial assessing the efficacy of Internet-based cognitive behavior therapy for procrastination, and was registered 04/22/2013 on ClinicalTrials.gov (NCT01842945).

Keywords: Procrastination, Psychometric evaluation, Irrational Procrastination Scale, Pure Procrastination Scale, Susceptibility to Temptation Scale

\footnotetext{
* Correspondence: alexander.rozental@psychology.su.se

${ }^{1}$ Division of Clinical Psychology, Department of Psychology, Stockholm

University, Frescati Hagväg 8, SE-106 91 Stockholm, Sweden

Full list of author information is available at the end of the article
} 


\section{Background}

Procrastination "to voluntarily delay an intended course of action despite expecting to be worse-off for the delay" (Steel, 2007, p. 66), is considered a prevalent self-regulatory failure that can result in personal distress and decreased well-being (Stead et al. 2010). In comparison to unintentionally postponing tasks and assignments, or having difficulties being self-assertive or prioritizing, procrastination is often regarded as a behavioral effect (Day et al. 2000), perpetuating most areas of life and causing troubles in the management of everyday commitments (Pychyl \& Flett, 2012). Procrastination has been associated with stress and anxiety, fewer mental-health seeking behaviors, the development and exacerbation of physical disorders, as well as problems initiating and following through different wellness behaviors, e.g., rehabilitation, dental check-ups, and physical exercise (Sirios, 2004; 2007). In addition, procrastination is also associated with poorer performance in school as well as work, and can have a detrimental effect on both financial decisions and career development (Steel et al. 2001; Tice \& Baumeister, 1997; O’Donoghue \& Rabin, 1999). Hence, procrastination can become severely debilitating, leading to major psychological suffering and have a negative impact on quality of life (Sirios et al. 2003).

Procrastination is estimated to affect approximately one-fifth of the adult population and half of the student population (Day et al. 2000; Harriott and Ferrari 1996). Studies also suggest that the number of people experiencing difficulties due to procrastination is on the rise, presumably because of greater access to immediate gratification through the use of modern information technology (Steel, 2012). However, the nature of procrastination is still unclear, and various ways of defining, conceptualizing, and explaining procrastination have been proposed (Steel, 2007). For instance, in an attempt to explore the relationship between procrastination and heredity, Gustavsson et al. (in press) found a genetic link between procrastination and impulsivity. Prior research has also investigated the association between different personality factors and procrastination, indicating that, in particular, a high degree of impulsiveness and a lack of self-control seems to be involved (Specter \& Ferrari, 2000; Tice \& Baumeister, 1997). Different theories of procrastination have also been put forward using motivational concepts, most recently the Temporal Motivational Theory (Steel \& König, 2006). According to Steel (2007), engagement in a given course of action is related to the expectation of achieving an anticipated outcome, the value of that outcome, the timing of the outcome, and the sensitivity to delay. Procrastination is thus characterized by having the intention to initiate or complete a task or assignment that will generate a certain value in the long run, but instead finding oneself pursuing other activities that are more readily enjoyable because of the timing of the reward and the ability to postpone gratification (Steel, 2010).

Different self-report measures have been developed in order to assess the occurrence and severity of procrastination, as well as to test the conceptual underpinnings of different theories of procrastination. Mann (1982; 1997) presented the Decisional Procrastination Questionnaire consisting of 30 items based on the notion of decisional procrastination, e.g., "I feel as if I'm under tremendous time pressure when making decisions" (item 1). Lay (1986) on the other hand developed the General Procrastination Scale, comprising 20 items of dilatory tendencies, e.g., "I generally delay before starting on work I have to do" (item 9). Furthermore, McCown et al. (1989) introduced the Adult Inventory of Procrastination, another general measure of procrastination, which includes fifteen items, e.g., "I don't get things done on time" (item 5). Solomon and Rothblum (1984) put forward the Procrastination Assessment Scale for Students, measuring the level of procrastination in six domains of curricular activity and the reasons behind procrastination, e.g., "You were concerned the professor wouldn't like your work" (item 19). However, according to a review by Steel (2010), the theoretical basis of many of the self-report measures have been found to be incoherent, particularly in terms of the idea of being able to differentiate various types of procrastination, i.e., arousal, avoidant, and decisional. It has also been suggested that decisional procrastination involve decisional avoidance rather than procrastination per se (Steel, 2007). In addition, Steel (2010) evaluated the psychometric properties of the self-report measures using factor analysis, revealing three distinct factors: a broad factor consisting of more general procrastination items, a second factor characterized by items that relate to keeping appointments and being in a rush, and a third factor that included items of promptness and the ability to perform tasks and assignments immediately. However, Steel (2010) argued that the results provided little evidence for a three-dimensional construct, particularly as only the first factor seemed to fit the definition of procrastination as being a voluntary delay. Steel (2010) therefore developed a new self-report measure using only items with the highest loadings on the first factor in the factor analysis, the Pure Procrastination Scale (PPS), consisting of twelve items deemed to determine dysfunctional delay, which was tested over the Internet on an Englishspeaking non-clinical population of 4169 participants. Furthermore, Steel (2010) proposed two additional self-report measures, the Irrational Procrastination Scale (IPS), which can be used as a parallel form to assess procrastination and allowing them to share validation efforts, and the Susceptibility to Temptation Scale (STS), examining the sensitivity to distractions and immediate gratification.

The results from Steel (2010) suggest that a single latent variable is sufficient to explain the nature of 
procrastination, namely, dysfunctional delay, and that selfreport measures trying to distinguish different types of procrastination are unwarranted. Similar results were obtained by Rebetez et al. (2014) when evaluating a French version of the PPS on a French-speaking non-clinical population of 245 participants. Hence, the PPS may become a valuable instrument for determining the occurrence and severity of procrastination, particularly in a clinical context where valid and reliable self-report measures are important in differential diagnosis and the assessment of treatment outcome. However, although Steel (2010) and Rebetez et al. (2014) have provided preliminary evidence for the use of the PPS, no attempt has yet been made to implement it in a clinical population. The current study thus seeks to explore the psychometric properties of the PPS in a clinical trial of Internet-based cognitive behavior therapy for procrastination (Rozental \& Carlbring, 2013). Furthermore, both the IPS and the STS are included in the analysis, as well as self-report measures of depression, anxiety, and quality of life, to further investigate the relationship between the respective instruments, as well as the potential association between self-report measures of procrastination and other types of psychiatric disorders. The purpose of the current study is thus to 1) explore the factor structure of the PPS, the IPS, and the STS in a self-referred clinical population 2) examine the discriminant and construct validity and reliability of the PPS, the IPS, and the STS in order to assess their psychometric properties, 3) evaluate the usefulness of the IPS as a self-report measure administered in a clinical trial by determining its test-retest reliability and minimal detectable change, and 4) investigate the correlations between the PPS, the IPS, and the STS, and self-report measures of depression, anxiety, and quality of life.

\section{Methods \\ Participants}

The current study is part of a clinical trial assessing the efficacy of Internet-based cognitive behavior therapy for procrastination (Rozental \& Carlbring, 2013), and was registered 04/22/2013 as a clinical trial on ClinicalTrials. gov (NCT01842945). Participants were recruited through reports in the Swedish media, advertisements on the Internet, and through information on Facebook (Ramo et al., 2014). Eligibility for treatment was determined via an online screening process consisting of open-ended questions and several self-report measures of procrastination, depression, anxiety, and quality of life.

In total, 710 participants completed the online screening process. Missing information on the sociodemographic characteristics were, however, found for six participants, but these were nonetheless included in the subsequent analyses as they provided complete values on the self-report measures. In the clinical trial (Rozental \& Carlbring, 2013),
494 participants were eligible for inclusion based on the following criteria: Swedish residency, fluent in Swedish, at least 18 years old, having access to a computer with Internet, and suffering from problems primarily related to procrastination based on a minimum of 32 points on the IPS (Steel, 2012). Exclusion criteria were: ongoing psychological treatment, psychotropic medication unless the dosage had been stable for at least twelve weeks prior to entering treatment, and other psychiatric conditions regarded as better cared for elsewhere, e.g., bipolar disorder, schizophrenia, psychosis, ADHD/ADD, and severe misuse of alcohol or drugs. In addition, severe depression and suicidal ideation were also reasons for exclusion, as indicated by having a minimum of 32 points, or scoring 3 points or above on question 9 regarding suicidality on the Montgomery Åsberg Depression Rating Scale - Selfreport version (MADRS-S; Svanborg \& Åsberg, 2001). For a full presentation of inclusion and exclusion criteria, consult the study protocol by Rozental and Carlbring (2013). A complete flow chart of the clinical trial can be seen in Figure 1. Enrollment and randomization into three conditions, guided self-help, unguided self-help, and wait-list control, however, involved 150 participants, as this was the maximum number of participants that were to be included in the clinical trial. Of these, only the 50 participants in the wait-list control were used in the investigation of test-retest reliability in the current study. Hence, this is the only analysis in the current study that is affected by the cut-offs and exclusion criteria of the clinical trial by Rozental and Carlbring (2013). With this exception, when assessing the psychometric properties of the self-report measures in the current study, all 710 participants were included, regardless of their baseline severity level of procrastination, or if they were excluded from the clinical trial due to fulfilling one or more exclusion criteria. The sociodemographic characteristics of all participants can be found in Table 1.

\section{Procedure}

Participants were required to log on to a secure online interface requiring registration and electronic identification, i.e., SLL Certificates, in order to complete an automated and fully computerized online screening process, minimizing the risk of data loss or data distortion (Carlbring et al., 2007; Thorndike et al., 2009). All data were stored encrypted in adherence with the Swedish Personal Data Act (Datainspektionen, 1998). When completing the online screening process and registering for the clinical trial, participants received an auto generated identification code, e.g., 1234abcd, ensuring anonymity throughout the screening process, treatment period, and analysis of the results. For the wait-list control, self-report measures using the IPS were administered weekly throughout the waiting period using the secure online interface, 


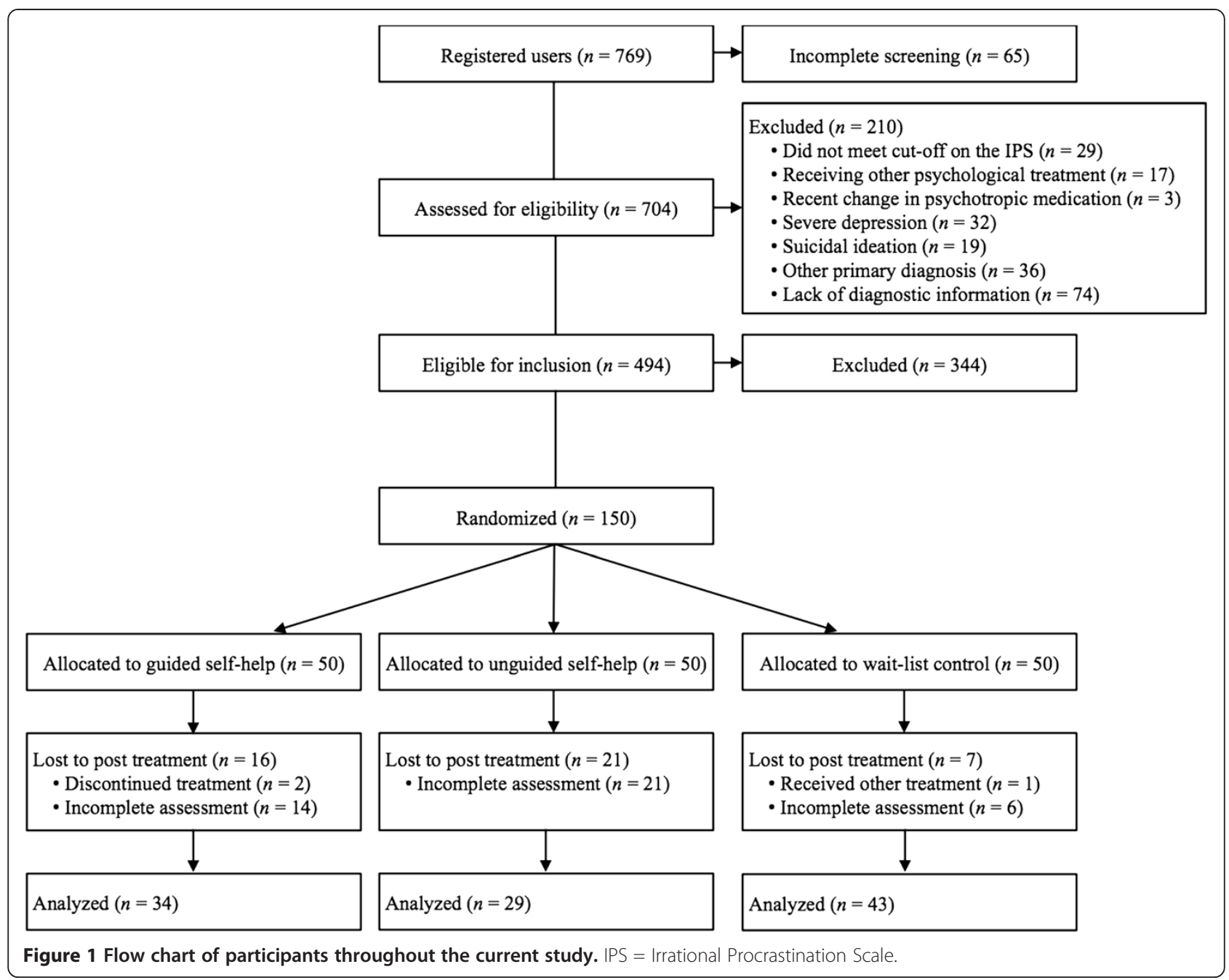

and only reminders to complete the self-report measures were sent to the participants' private email. All participants completed the screening process during the period of August through September 2013, and the weekly measures were carried out during the treatment period, ranging from September to November 2013.

\section{Ethics}

The clinical trial, which the current study is a part of, received ethical approval from the Regional Ethical Board in Stockholm, Sweden (Dnr 2013/974-3175). Written informed consent was required by all participants in order to be considered eligible for participation. Great consideration was given to ensure that no participants were included while having another condition that might have required more immediate attention, in which case they were contacted with information on where to find relevant help. In addition, deterioration was closely monitored by the study supervisors in case the condition of a participant worsened and might require more specialized care. Potential negative effects were also investigated using open-ended questions concerning their characteristics and severity at post treatment assessment (Rozental et al., 2014), and reliable deterioration was explored using the Reliable Change Index (Boettcher et al. 2014). For ethical reasons, the participants in the wait-list control received unguided self-help after the first treatment period had ended.

\section{Measures}

Included in the current study were two self-report measures of procrastination, the PPS (Steel, 2010), and the IPS (Steel, 2010), as well as one self-report measure of susceptibility to temptation, the STS (Steel, 2010), all of which were developed and tested over the Internet. The instruments were translated into Swedish by an authorized translator (see the Table 2 for both the English and Swedish versions). The PPS features twelve items measuring the prevalence of procrastination and was developed to increase the validity of several already existing procrastination scales (Steel, 2010). The English version of the PPS has a good internal consistency, Cronbach's $\alpha=.92$, 
Table 1 Sociodemographic characteristics of the participants

\begin{tabular}{|c|c|c|}
\hline & $\begin{array}{l}\text { Screening } \\
\text { sample } \\
(n=710)\end{array}$ & $\begin{array}{l}\text { Wait-list } \\
\text { sample } \\
(n=50)\end{array}$ \\
\hline Gender: $n$ (\% female) & $308(43.4)$ & $23(46.0)$ \\
\hline Age (years): $M(S D)$ & $38.59(11.0)$ & $41.56(9.9)$ \\
\hline \multicolumn{3}{|l|}{ Marital status: $\boldsymbol{n}(\%)$} \\
\hline Single & $208(28.7)$ & $17(34.0)$ \\
\hline Married/Partner & $448(63.1)$ & $28(56.0)$ \\
\hline Divorced/Widow & $42(5.9)$ & $4(8.0)$ \\
\hline Other & $10(1.4)$ & $1(2.0)$ \\
\hline Children: $n$ (\% yes) & $340(47.9)$ & $22(44.0)$ \\
\hline \multicolumn{3}{|l|}{ Highest educational level: $\boldsymbol{n}(\%)$} \\
\hline Middle school & $18(2.5)$ & $1(2.0)$ \\
\hline High school/college & $287(40.4)$ & $13(26.0)$ \\
\hline University & $372(52.4)$ & $32(64.0)$ \\
\hline Postgraduate & $27(3.8)$ & $4(8.0)$ \\
\hline Sick leave: $n$ (\%) & $17(2.4)$ & $0(0.0)$ \\
\hline $\begin{array}{l}\text { Previous psychological treatment: } \\
n \text { (\% yes) }\end{array}$ & $322(45.4)$ & $24(48.0)$ \\
\hline $\begin{array}{l}\text { Previous psychotropic medication: } \\
n \text { (\% yes) }\end{array}$ & $199(28.0)$ & $11(22.0)$ \\
\hline
\end{tabular}

Note: Screening sample contains missing values on the sociodemographic characteristics of six participants and is therefore based on $n=704$. However, all subsequent analyses include data from $n=710$.

and shows convergent validity with other related measures. The IPS features nine items measuring the degree of irrational delay causing procrastination, and its English version has yielded a good internal consistency, Cronbach's $\alpha=.91$, and correlates with PPS at $r=.87$, or $r=.96$, after correcting for attenuation due to unreliability (Steel, 2010). The STS features eleven items measuring the susceptibility to temptation, affecting the ability to initiate and complete tasks and assignments. The English version of the STS has a good internal consistency, Cronbach's $\alpha=.89$, and correlates with both the PPS and the IPS at $r=.69$ (Steel, 2010).

Additional self-report measures of depression, anxiety, and quality of life were also included in the current study, using the Swedish version of the MADRS-S (Svanborg \& Åsberg, 2001; Holländare et al. 2010), the Generalized Anxiety Disorder Assessment 7-item (GAD-7; Spitzer et al., 2006; Dear et al., 2011), and the Quality of Life Inventory (QOLI; Frisch et al., 1992; Lindner et al., 2013). The MADRS-S is a self-assessment version of the MADRS, featuring nine items measuring changes in mood, anxiety, sleeping patterns, appetite, concentration, initiative, emotional engagement, pessimism and attitude towards life. The MADRS-S has been evaluated over the Internet with an internal consistency similar to the paper version, Cronbach's $\alpha$ between .73 and .81 , as well as a high correlation between the formats, $r=.84$ (Holländare et al. 2010). The GAD-7 features seven items for assessing anxiety and screening for generalized anxiety disorder, and has been assessed over the Internet with a good internal consistency, Cronbach's $\alpha=.79$, and with large correlations to other related measures of anxiety and worry at post treatment, $r=.68$ to .76 (Dear et al., 2011). The QOLI features 32 items concerning 16 areas of life rated by the participants with regard to importance and satisfaction, and has been shown to have a good internal consistency, Cronbach's $\alpha$ between .71 and .83 , when administered over the Internet (Lindner et al., 2013).

\section{Statistical analysis}

Prior to analysis, the distribution of data was assessed and levels of skewness and kurtosis were found to be acceptable for analysis. In addition, Keiser-Meyer-Olkin's test of sampling adequacy (KMO) and Bartlett's test of sphericity showed that the data was highly suitable for factor analysis.

Principal Component Analysis (PCA) with Varimaxrotation was performed to assess the component structure of the Swedish versions of the IPS, the PPS, and the STS in order to explore how these instruments behave in a novel sample as well as language, rather than confirming any hypothesis regarding their respective component structure. This approach was chosen based on the recommendations by Cichetti (1994), as the current sample had different characteristics than the ones used in the studies by Steel (2010) and Rebetez et al. (2014). Included in the current study are participants who perceived themselves to be in need of treatment for procrastination, while the samples in the original studies by Steel (2010) and Rebetez et al. (2014) were not explicitly seeking treatment. Furthermore, as the current study intended to investigate the component structure of the instruments in Swedish, the approach was explorative, and the use PCA was thus deemed appropriate.

Analyses of how all of the different measures correlated with each other were also performed, including the MADRS-S, the GAD-7, and the QOLI. Corrections for attenuation due to unreliability was performed using the formula $r_{x^{\prime} y^{\prime}}=r^{x y} /\left(\sqrt{ } r_{x x} r_{y y}\right)$ (Zimmerman, 2007).

Cronbach's $\alpha$ was used as an indication of internal consistency. A two-way random effect single measure was used as an indicator of Intraclass Coefficient Correlation (ICC; Baldwin et al., 2011), following the recommendations in McGraw and Wong (1996). Absolute agreement, in accordance to McGraw and Wong (1996), was used as a measure of coherence.

Standard Error of Measurement (SEM) was defined as the square root of the mean square error in the ANOVA (Weir 2005). This was then used to calculate the Minimal Detectable Change (MDC) defined as SEM x $1.96 \times k$, 
Table 2 Original and translated versions of the self-report measures

Pure Procrastination Scale (PPS), with the Swedish version given in italics

English version

PPS1 I delay making decisions until it's too late

PPS2 Even after I make a decision I delay acting upon it

PPS3 I waste a lot of time on trivial matters before getting to the final decisions

PPS4 In preparation for some deadlines, I often waste time by doing other things

PPS5 Even jobs that require little else except sitting down and doing them, I find that they seldom get done for days

PPS6 I often find myself performing tasks that I had intended to do days before

PPS7 I am continually saying "I'Il do it tomorrow"

PPS8 I generally delay before starting on work I have to do

PPS9 | find myself running out of time

PPS10 I don't get things done on time

PPS11 I am not very good at meeting deadlines

PPS12 Putting things off till the last minute has cost me money in the past
Swedish translation

Jag skjuter upp beslut tills det är försent

Även efter att jag har fattat ett beslut dröjer det innan jag agerar i enlighet med det

Jag kastar bort mycket tid på bagateller innan jag fattar ett slutgiltigt beslut

När jag måste hålla en tidsgräns slösar jag ofta bort tiden på annat

Även när det gäller arbeten som inte är särskilt krävande kan det ta mig flera dagar att slutföra dem

Jag ägnar mig ofta åt saker som jag hade tänkt att göra för flera dagar sedan

Jag säger hela tiden att "det där gör jag imorgon"

Jag väntar vanligtvis med att påbörja ett arbete som jag måste göra

Det känns som om tiden inte räcker till

Jag fär inte saker och ting gjorda i tid

Jag är inte bra på att hålla utlovade tider

Att skjuta upp saker och ting till sista minuten har tidigare stått mig dyrt

\section{Irrational Procrastination Scale (IPS), with the Swedish version given in italics}

\section{English version}

IPS1 I put things off so long that my well-being or efficiency unnecessarily suffers

IPS2 If there is something I should do, I get to it before attending to lesser tasks (R)

IPS3 My life would be better if I did some activities or tasks earlier

IPS4 When I should be doing one thing, I will do another

IPS5 At the end of the day, I know I could have spent the time better

IPS6 I spend my time wisely (R)

IPS7 I delay tasks beyond what is reasonable

IPS8 I procrastinate

IPS9 I do everything when I believe it needs to be done (R)

Note: Items 2,6, and 9 are scored in reverse (R)
Swedish translation

Jag skjuter upp saker och ting så pass länge att mitt välbefinnande eller min effektivitet blir lidande

Om det är något jag borde göra, tar jag tag i det innan jag börjar med mindre betydelsefulla uppgifter ( $R$ )

Jag skulle må bättre om jag slutförde saker och ting tidigare

När jag borde göra en sak så gör jag något annat istället

När dagen är slut upplever jag att jag hade kunnat utnyttja min tid bättre Jag använder min tid väl (R)

Jag skjuter upp mina uppgifter mer än vad som är rimligt

Jag förhalar saker och ting

Jag gör allt när jag anser att det behöver göras (R)

Susceptibility to Temptation Scale (STS), with the Swedish version given in italics

English version

STS1 I will crave a pleasurable diversion so sharply that I find it increasingly hard to stay on track

STS2 I feel irresistibly drawn to anything interesting, entertaining, or enjoyable

STS3 I have a hard time postponing pleasurable opportunities as the gradually crop up

STS4 When an attractive diversion comes my way, I am easily swayed

STS5 My actions and words satisfy my short-term pleasures rather than my long-term goals

STS6 I get into jams because I will get entranced by some temporarily delightful activity

STS7 It takes a lot for me to delay gratification

STS8 When a task is tedious, again and again I find myself pleasantly daydreaming rather than focusing

\section{Swedish translation}

Jag har ett så stort behov att ägna mig åt annat som är angenämt att jag får allt svårare att koncentrera mig på det jag ska göra

Jag känner en oemotståndlig dragningskraft till allt som är intressant, underhållande eller trevligt

Jag har svårt att skjuta upp nöjen i samband med att de dyker upp

Jag blir lätt distraherad när det dyker upp något som lockar

Det jag säger och gör skänker mig en kortsiktig njutning snarare än att tillgodose mina långsiktiga mål

Jag får problem eftersom jag lätt blir distraherad av en tillfällig och tilltalande aktivitet

Det krävs en stor uppoffring för mig att skjuta upp något som ger mig tillfredsställelse

När jag jobbar med en tråkig uppgift händer det ofta att jag dagdrömmer om annat än att fokusera på mitt arbete 


\section{Table 2 Original and translated versions of the self-report measures (Continued)}

\begin{tabular}{lll}
\hline STS9 When a temptations is right before me, the craving can be & $\begin{array}{l}\text { Om jag står inför något som frestar mig så upplever jag ett starkt begär att } \\
\text { intense } \\
\text { falla till föga }\end{array}$ \\
STS10 I choose smaller but more immediate pleasures over those larger & $\begin{array}{l}\text { Jag väljer mindre men mer omgående nöjen än de som är större och tar } \\
\text { but more delayed }\end{array}$ & längre tid att nå \\
STS11 I take on new tasks that seem fun at first without thinking & Jag tar på mig nya uppgifter som framstår som roliga utan att tänka \\
through the repercussions & igenom vilka följder det kan få
\end{tabular}

where 1.96 represents a 95\% confidence interval in a $z$ distribution, and $k$ is the number of measurements (in our case 2) as described by Wier (2005). All statistical analyses were made in SPSS version 21.

\section{Results}

\section{Distribution of data}

An initial analysis of the data showed that IPS, PPS and STS were approximately normally distributed, see Table 3. There were some high values in the sample, but this was probably due to the fact that the participants were seeking treatment for difficulties related to procrastination. According to the results of the KMO and Bartlett's test of sphericity the data was suitable for a factor analysis.

\section{Validity}

\section{Factor validity of the IPS}

The PCA with Varimax-rotation of the IPS generated two factors with eigenvalues of one or more. The screeplot was examined to ensure that the two factor solution seemed reasonable, after which it was retained. For the exploratory purposes of this analysis the cut off for factor loadings was set to .40 . Smaller coefficients are not reported in Tables 3 and 4 . The first factor reflected the suggestion by Steel (2010) regarding the unidimensionality of the IPS, which seems to measure general procrastination. It accounted for $35 \%$ of the variance and had an eigenvalue of 3.24. The second factor extracted had an eigenvalue of 1.06 and contained items 2, 6 and 9, which are scored in reverse, for instance, "I do everything when I believe it needs to be done" (item 9). Factor loadings for the items in the IPS are presented in Table 4. The second factor is however most likely an artifact of the instrument, reflecting the fact that the participants simply missed the double negatives or reversed items despite being included in the scale to prevent mindless responses. Artifactual response factors containing all reversed items in a scale are a relatively common issue in scale development (Hinkin, 1995). This seems reasonable since the item-scores of 1 and 2 points, that is, after the scores have been reversed, appeared in the current sample 129 times in total for the IPS, with 105 of these being responses to the three reversed items. Furthermore, "I spend my time wisely" (item 6), cross-loaded and had a lower loading on the second factor, possibly reflecting the relatively short and concise phrasing of the item, leaving it less open to misinterpretation than items 2 and 9.

\section{Factor validity of the PPS and the STS}

The PCA of the PPS generated four factors that met the Keiser-criterion of eigenvalue one or higher. However, since the average communality was less than .60 , the screeplot, the number of items per factor, the cross-loadings, and the number of non-trivial factors were examined to determine the number of factors to extract (Zwick \& Velicer, 1986). Finally two factors were selected, accounting for $40.92 \%$ of the variance. Varimax-rotation was performed and the resulting factor loadings for the PPS are reported in Table 5 . These focused on delaying decision making, not meeting deadlines, and missing appointments (factor 1), compared to starting late, lagging behind, and wasting time on other things (factor 2), but not items regarding failure.

While both of these components seem relevant when assessing clinical levels of procrastination, the first factor does not necessarily fall completely within the current definition of procrastination, i.e., the definition of procrastination does necessitate failure. Repeated failure is on the other hand quite relevant when assessing a clinical procrastinator as it may cause, or moderate, psychological distress, and quality of life. In order to investigate this further, scores from the two components of the PPS were correlated with the MADRS-S, the GAD-7 and the QOLI, as shown in Table 6. These coefficients were twice and almost four times larger for factor 1 , the one including failure; $r={ }^{ \pm} .27$ to $.31, p<0.01$, than for component $2, r={ }^{ \pm} .07$ to $.15, p<0.01$, indicating that this factor may be associated with psychological distress rather than exclusively assessing irrational delay. The correlation with the IPS was also markedly larger for

Table 3 Data distribution for the Irrational Procrastination Scale (IPS), the Pure Procrastination Scale (PPS), and the Susceptibility to Temptation Scale (STS)

\begin{tabular}{llllll}
\hline & Mean (SD) & Skewness & Kurtosis & KMO & Bartlett \\
\hline IPS & $38.47(3.62)$ & -0.496 & 0.070 & 0.844 & $p<0.0001$ \\
PPS & $49.26(5.69)$ & -0.402 & -0.231 & 0.831 & $p<0.0001$ \\
STS & $42.02(7.07)$ & -0.428 & -0.017 & 0.909 & $p<0.0001$ \\
\hline
\end{tabular}

Note: Table of mean, skewness, kurtosis, KMO test of sampling adequacy and Bartlett's test of sphericity. 
Table 4 Rotated component matrix for a two factor solution of the Irrational Procrastination Scale (IPS)

\begin{tabular}{|c|c|c|c|}
\hline & & Factor 1 & Factor 2 \\
\hline IPS1 & $\begin{array}{l}\text { I put things off so long that my well-being } \\
\text { or efficiency unnecessarily suffers }\end{array}$ & .69 & \\
\hline IPS2 & $\begin{array}{l}\text { If there is something I should do, I get } \\
\text { to it before attending to lesser tasks (R) }\end{array}$ & & .72 \\
\hline IPS3 & $\begin{array}{l}\text { My life would be better if I did some } \\
\text { activities or tasks earlier }\end{array}$ & .68 & \\
\hline IPS4 & $\begin{array}{l}\text { When I should be doing one thing, } \\
\text { I will do another }\end{array}$ & .55 & \\
\hline IPS5 & $\begin{array}{l}\text { At the end of the day, I know I } \\
\text { could have spent the time better }\end{array}$ & .64 & \\
\hline IPS6 & I spend my time wisely (R) & .43 & .46 \\
\hline IPS7 & $\begin{array}{l}\text { I delay tasks beyond what is } \\
\text { reasonable }\end{array}$ & .64 & \\
\hline IPS8 & I procrastinate & .64 & \\
\hline IPS9 & $\begin{array}{l}\text { I do everything when I believe } \\
\text { it needs to be done (R) }\end{array}$ & & .79 \\
\hline
\end{tabular}

Note: Items designated with an (R) are reversed, meaning that a score of 5 instead equals 1. Extraction method: Principal component analysis. Rotation method: Varimax-rotation with Keiser normalization. Coefficients smaller than .40 are suppressed.

Table 5 Rotated component matrix for the two factor solution of the Pure Procrastination Scale (PPS)

\begin{tabular}{|c|c|c|c|}
\hline & & Factor 1 & Factor 2 \\
\hline PPS1 & $\begin{array}{l}\text { I delay making decisions until it's too } \\
\text { late }\end{array}$ & .67 & \\
\hline PPS2 & $\begin{array}{l}\text { Even after I make a decision I delay } \\
\text { acting upon it }\end{array}$ & .44 & \\
\hline PPS3 & $\begin{array}{l}\text { I waste a lot of time on trivial matters } \\
\text { before getting to the final decisions }\end{array}$ & .68 & \\
\hline PPS4 & $\begin{array}{l}\text { In preparation for some deadlines, I } \\
\text { often waste time by doing other things }\end{array}$ & & .49 \\
\hline PPS5 & $\begin{array}{l}\text { Even jobs that require little else except } \\
\text { sitting down and doing them, I find that } \\
\text { they seldom get done for days }\end{array}$ & & .72 \\
\hline PPS6 & $\begin{array}{l}\text { I often find myself performing tasks } \\
\text { that I had intended to do days before }\end{array}$ & & .45 \\
\hline PPS7 & $\begin{array}{l}\text { I am continually saying "I'll do it } \\
\text { tomorrow" }\end{array}$ & & .57 \\
\hline PPS8 & $\begin{array}{l}\text { I generally delay before starting on } \\
\text { work I have to do }\end{array}$ & & .77 \\
\hline PPS9 & I find myself running out of time & .53 & \\
\hline PPS10 & I don't get things done on time & .59 & \\
\hline PPS11 & I am not very good at meeting deadlines & .64 & \\
\hline PPS12 & $\begin{array}{l}\text { Putting things off till the last minute has } \\
\text { cost me money in the past }\end{array}$ & .46 & \\
\hline
\end{tabular}

Note: Extraction method: Principal component analysis. Rotation method: Varimax-rotation with Keiser normalization. Coefficients smaller than .40 are suppressed.
Table 6 Correlates between factor scores for the Pure Procrastination Scale (PPS) two factor solution and the other scales

\begin{tabular}{llllll}
\hline PPS & GAD-7 & MADRS-S & QOLI & IPS & STS \\
\hline Factor 1 & 0.31 & 0.28 & -0.27 & 0.35 & 0.29 \\
Factor 2 & 0.15 & 0.10 & -0.07 & 0.54 & 0.33 \\
\hline
\end{tabular}

Note: All correlations are significant, $p<.01$. Factor 1 includes failure to meet deadlines and being too late whilst factor 2 seems to strictly deal with irrational delay.

component 2 giving further evidence to the notion that those items deal purely with irrational delay.

The PCA of the STS generated a single factor with an eigenvalue of at least one, i.e., 4.98, which alone accounted for $45.24 \%$ of the variance. This means that the STS seem to measure a single component, that is, susceptibility to temptation.

\section{Reliability}

\section{Reliability estimates}

Means, standard deviations, reliability estimates, and intercorrelations for all of the included scales are displayed in Table 7. All instruments were significantly correlated, $p<0.01$. The IPS and the PPS correlated moderately, $r=.61, p<0.01$, or $r=.79$, after correcting for attenuation due to unreliability (presented below within parentheses). Both instruments correlated weakly with the STS, $r=.32$ and $r=.44, p<0.01$. Correlations between the IPS, the PPS, the STS and the other instruments (the MADRS-S, the GAD-7 and the QOLI) indicated some discriminant validity. While all correlations were statistically significant, the corrected coefficients were notably smaller for these scales, ranging from $r=-.17(-.21)$ to $r=.35(.42)$ than within the procrastination battery. The only exception was the STS being nearly as correlated to the IPS as it was to the GAD-7. Furthermore, corrected correlations between the MADRS-S, the GAD-7, and the QOLI were stronger than with the procrastination scales, ranging from $r=-.40$ $(-.48)$ to $r=.66$ (.77), indicating two separate groups of variables.

\section{Reliability and minimal detectable change for the IPS}

The IPS had a good internal consistency, Cronbach's $\alpha=.76$ (if separated, the procrastination factor had an internal consistency of .72, and the reversed score factor had .53), and all the items in the instrument were judged worthy of retention since there were no items whose absence would raise the alpha-level notably. All items correlated with the full scale at an acceptable level considering the sample size, lowest being $r=.34$.

Correlations between successive weekly measurements on the IPS ranged from .73 to .90 , with a median of .84 . This was based on the results from the IPS when administered between week two and three, as these two weekly 
Table 7 Reliability and correlates among instruments

\begin{tabular}{|c|c|c|c|c|c|c|c|c|c|}
\hline & & $M$ & $S D$ & $a$ & 1 & 2 & 3 & 4 & 5 \\
\hline 1 & IPS & 38.47 & 3.62 & 0.76 & & & & & \\
\hline 2 & PPS & 49.26 & 5.69 & 0.78 & $0.61(0.79)$ & & & & \\
\hline 3 & STS & 42.02 & 7.07 & 0.87 & $0.32(0.39)$ & $0.44(0.53)$ & & & \\
\hline 4 & GAD-7 & 8.31 & 5.26 & 0.88 & $0.30(0.37)$ & $0.35(0.42)$ & $0.26(0.30)$ & & \\
\hline 5 & MADRS-S & 16.47 & 7.69 & 0.83 & $0.26(0.33)$ & $0.28(0.35)$ & $0.17(0.20)$ & $0.66(0.77)$ & \\
\hline 6 & QOLI & 0.41 & 1.73 & 0.79 & $-0.19(-0.25)$ & $-0.25(0.32)$ & $-0.17(-0.21)$ & $-0.40(-0.48)$ & $-0.59(-0.73)$ \\
\hline
\end{tabular}

self-report measures had the highest number of valid observations, $n=46$. The ICC and subsequent analyses were therefore carried out with the data from these weeks. This produced an ICC of .83, indicating excellent reliability, ICC > .75 (Marx et al., 2003). SEM for the IPS was 1.61, and the MDC for the IPS was estimated to 4.47 points. Hence, a change in IPS-score of 4.47 is to be considered a statistically significant difference, i.e., real, $p<0.05$.

\section{Reliability of the PPS and the STS}

The PPS and the STS were also shown to have a good internal consistency, Cronbach's $\alpha=$ for PPS was .78 (if separated, the two factors found in PCA had Cronbach a of .72 and .69). In terms of the STS, Cronbach's $\alpha=.87$, and all of the questions in the scales were deemed worthy of retention. The lowest item-total correlation was .29 for both the PPS and the STS. The correlations between the scales and the internal consistencies for the IPS, the PPS and the STS can be obtained in Table 7.

\section{Discussion}

The PCA for the IPS revealed two factors. The first factor representing general procrastination, accounting for $35 \%$ of the variance, and a second factor that simply seemed to reflect the reverse items in the scale. Hence, the IPS seems to be unidimensional, as proposed by Steel (2010), while having an artifact imbedded in the reverse scored items, possibly due to carelessness or satisficing, that is, skimming through the response alternatives in order to preserve cognitive resources (Hinkin, 1995; Schmitt \& Stults, 1985; Harvey et al. 1985). Further research is needed in order to assess if the reverse items can be rephrased so that the meaning of the items will be clearer, and to investigate how this can affect the factor structure. The PCA for the PPS generated a two factor solution, explaining approximately $41 \%$ of the variance. Both factors seem to be associated with voluntary delay, suggesting there may be a single higher order factor being measured, which is consistent with the conclusions of Steel (2010) and Rebetez et al. (2014). However, the first factor was made up of items dealing not only with delay, but also with failure to meet deadlines and finishing tasks, and was far more correlated with depression, anxiety, and poor quality of life than the second factor. Hence, in a clinical population, the PPS seems to measure procrastination accurately, that is, voluntary delay, but may also consist of a subset of items that measure procrastination-associated failures, and indirectly the impact of procrastination on one's psychological wellbeing. Although these findings are preliminary and need to be replicated, Rebetez et al. (2014) found similar evidence for two separate factors, one being related to voluntary delay, and the other being associated with observed delay, that is, the observation of running out of time and not meeting deadlines. The item loadings of the two factors do, however, differ between the current study and that of Rebetez et al. (2014), namely, that items 1-3 load on general procrastination (or voluntary delay) in Rebetez et al. 2014), while these items load on the failure to meet deadlines in the current study (or observed delay). These three items all involve decision-making, originally emanating from the Decisional Procrastination Questionnaire (Mann et al. 1997). Since Steel (2010) found no evidence for the decisional subtype of procrastinators these items may need to be rephrased in light of these inconsistent findings. Furthermore, Rebetez et al. (2014) found a floor effect on item 12 of the PPS, with $80 \%$ of the responses being either 1 or 2 . However, the current study found the opposite results, with $66 \%$ of the responses being either 4 or 5. This could indicate that the current study and Rebetez et al. (2014) comprised two distinct populations, and that the PPS picks up different factors accordingly, or, alternatively, that it reflects the removal of the word "money" from the Swedish translation.

In terms of the STS, the PCA revealed only a single factor, accounting for more than $45 \%$ of the variance, that is, susceptibility of temptation, and is coherent with the findings of Steel (2010).

The similarities between Steel (2010) and the current study are further confirmed by the correlations between the different scales. The results indicate a high correlation between the IPS and the PPS, $r=.79$, which is at a similar level, $r=.87$, to Steel (2010). This gives further evidence for the unidimensionality of the instruments, and that they can be used interchangeably to share validation efforts. The STS, measuring a different component, 
correlates to the IPS and the PPS at $r=.39$ to .53 , which is comparable to the results obtained by Steel (2010), $r=.69$. The small difference might be explained by the fact that the current study was part of a clinical trial that focused on problems related to procrastination, rather than susceptibility to temptation.

All of the scales yielded good to excellent reliability with Cronbach's $\alpha$, ranging from .78 to .87 , as well as the ICC for the IPS being .83. In addition, the SEM for the IPS was 1.61 and the MDC 4.47 points, indicating that, in reality, a change of almost five points on the scale is necessary to determine a reliable change in procrastination, which is of particular importance in a clinical context. However, five points may not necessarily indicate a good treatment outcome, and the post treatment results thus need to be considered in light of the baseline severity level.

Furthermore, the correlation matrix showed that the procrastination scales did not correlate highly, $r=-.17$ to -.35 (-.25 to .42 corrected for attenuation due to unreliability), with the other measures of depression, anxiety, and quality of life, suggesting that they do not measure an overlapping construct and are different from each other.

The current study has several limitations that need to be considered when interpreting the results. First, the population recruited for the clinical trial consisted of self-referred participants who perceived themselves to be in need of treatment for procrastination. However, as procrastination is not considered a psychiatric condition, no structured clinical interview could be implemented in order to establish the occurrence and severity of procrastination, for instance, the Structured Clinical Interview for DSM-IV (SCID; First et al., 1996). Hence, the participants may not necessarily have had a clinical problem of procrastination, warranting further research in order to determine whether the self-report measures evaluated in the current study can be used to distinguish a clinical from non-clinical population. Second, although the population was similar to that of Steel (2010) in terms of mean age (38.59 compared to 37.4 ) and gender (43.4\% compared to $57.4 \%$ females), the participants may be somewhat older than the average individual experiencing difficulties due to procrastination. According to Steel (2007), problems of procrastination decrease with age, being most prevalent and severe among teenagers and students. The occurrence and severity of procrastination might therefore be more manifest and troublesome for a younger population, which might affect the validity and reliability of the self-report measures used in the current study, and in turn motivate further research. Third, the fact that the participants actively sought treatment could, in itself, be regarded as uncharacteristic of a typical procrastinator, potentially making the population in the current study somewhat different to procrastinators in general. Forth, the instruments used in the current were distributed via the Internet, which might not necessarily correspond to a paper-andpen administration. However, prior research comparing various self-report measures completed via either the Internet or by paper-and-pen have not found any evidence that the format would affect the responses in a way that would limit their validity or reliability (Luce et al., 2007; Holländare et al., 2010; Grieve \& de Groot, 2011; Lindner et al., 2013), indicating that the instruments in the current study might be just as useful when administered by paperand-pen.

Additional research is warranted in terms of investigating the relationship between various self-report and behavioral measures of procrastination. Preliminary evidence by Krause and Freund (2014) have for instance shown that there might be a difference between assessing procrastination by self-report and behavioral measures, and that self-report measures seem to be more associated with well-being than behavioral measures. In addition, establishing a cut-off to distinguish clinical from non-clinical samples of procrastinators using self-report measures is important, as well as to explore the usefulness of the scales in a clinical context (Klingsieck, 2013). Furthermore, another important issue regarding the different scales is to explore if there are different types of procrastinationrelated difficulties, which in turn could help tailor the treatment interventions to the specific type. Any future psychometric investigation of the scales should also involve a Confirmatory Factor Analysis in order to further clarify and replicate the findings of Steel (2010), Rebetez et al. (2014), and the current study, in terms of the factor structure of the IPS, PPS and STS.

\section{Conclusions}

The Swedish translation of the scales in the current study seem to measure one general form of procrastination, that is, voluntary delay, as well as susceptibility to temptation, and are deemed both valid and reliable for assessing the occurrence and severity of procrastination via the Internet. The current study supports the use of the scales in a clinical and a non-clinical context in Swedish and similar populations.

\section{Abbreviations \\ IPS: Irrational Procrastination Scale; PPS: Pure Procrastination Scale; STS: Susceptibility to Temptation Scale; MADRS-S: Montgomery Åsberg Depression Rating Scale - Self-report version; GAD-7: Generalized Anxiety Disorder Assessment 7-item; QOLI: Quality of Life Inventory; KMO: Keiser-Meyer- Olkin's test of sampling adequacy; PCA: Principal Component Analysis; ICC: Intraclass Correlation Coefficient; SEM: Standard Error of Measurement; MDC: Minimal Detectable Change.}

\section{Competing interests}

The current study is part of a clinical trial assessing the efficacy of Internetbased cognitive behavior therapy for procrastination (Rozental \& Carlbring, 2013), which in turn was based on a self-help book specifically for targeting problems related to procrastination that was written and released on the 
Swedish market by the main author, Alexander Rozental. None of the other authors have declared any competing interests.

\section{Author's contributions}

All of the statistical analyses in the current study were performed by EF and AS, who also wrote a draft of the results. GA and PC were the main supervisors during the statistical analysis and managed all of the subsequent revisions of the manuscript. AR was the principal investigator of the clinical trial in which the current study is included, coordinated the work, and wrote a draft of the background. DF was the secondary supervisor during the statistical analysis, and wrote a draft of the method. All of the authors contributed equally to the discussion and conclusion. All authors read and approved the final manuscript.

\section{Acknowledgements}

The current study was made possible in part by a grant from the Swedish Research Council (2011-38394-87877-7) to the sixth author, as well as a grant from Linköping University to the fifth author. None of the granting sources were involved in the preparation or execution of the current study, and were not a part of the statistical analyses or drafting of the manuscript. The authors of the current study would like to thank Piers Steel for allowing a Swedish translation and use of the Pure Procrastination Scale, the Irrational Procrastination Scale, and the Susceptibility to Temptation Scale, as well as for providing background information and being of assistance during the data analysis.

\section{Author details}

'Division of Clinical Psychology, Department of Psychology, Stockholm University, Frescati Hagväg 8, SE-106 91 Stockholm, Sweden. ²Department of Behavioural Sciences and Learning, Linköping University, Linköping, Sweden. ${ }^{3}$ Department of Clinical Neuroscience, Division of Psychiatry, Karolinska Institutet, Stockholm, Sweden.

\section{Received: 19 August 2014 Accepted: 24 November 2014 Published online: 11 December 2014}

\section{References}

Baldwin, SA, Murray, DM, Shadish, WR, Pals, SL, Holland, JM, Abramowitz, JS, Andersson, G, Atkins, DC, Carlbring, P, Carroll, KM, Christensen, A, Eddington, KM, Ehlers, A, Feaster, DJ, Keijsers, GP, Koch, E, Kuyken, W, Lange, A, Lincoln, T, Stephens, RS, Taylor, S, Trepka, C, \& Watson, J. (2011). Intraclass correlation associated with therapists: estimates and applications in planning psychotherapy research. Cognitive Behaviour Therapy, 40(1), 15-33. http:// dx.doi.org/10.1080/16506073.2010.520731.

Boettcher, J, Rozental, A, Andersson, G, \& Carlbring, P. (2014). Side effects in Internet-based interventions for social anxiety disorder. Internet Interventions, 1(1), 3-11. http://dx.doi.org/10.1016/j.invent.2014.02.002.

Carlbring, P, Brunt, S, Bohman, S, Richards, JC, Öst, L-G, \& Andersson, G. (2007). Internet vs. paper and pencil administration of questionnaires commonly used in panic/agoraphobia research. Computers in Human Behavior, 23, $1421-$ 1434. http://dx.doi.org/10.1016/j.chb.2005.05.002.

Cicchetti, DV. (1994). Guidelines, criteria, and rules of thumb for evaluating normed and standardized assessment instruments in psychology. Psychological Assessment, 6(4), 284-290. http://dx.doi.org/10.1037/10403590.6.4.284

Datainspektionen. (1998). Personal Data Act (1998:204). Stockholm: Datainspektionen.

Day, V, Mensink, D, \& O'Sullivan, M. (2000). Patterns of academic procrastination. Journal of College Reading and Learning, 30, 120-134.

Dear, BF, Titov, N, Sunderland, M, McMillan, D, Anderson, T, Lorian, C, \& Robinson, E. (2011). Psychometric Comparison of the Generalized Anxiety Disorder Scale-7 and the Penn State Worry Questionnaire for Measuring Response during Treatment of Generalised Anxiety Disorder. Cognitive Behaviour Therapy, 40(3), 216-227. http://dx.doi.org/10.1080/16506073.2011.582138.

First, MB, Spitzer, RL, Gibbon, M, \& Williams, JBW. (1996). Structured Clinical Interview for DSM-IV Axis I Disorders. Washington: American Psychiatric Press Inc.

Frisch, MB, Cornell, J, Villanueva, M, \& Retzlaff, PJ. (1992). Clinical validation of the quality of life inventory: a measure of life satisfaction for use in treatment planning and outcome assessment. Psychological Assessment, 4(1), 92-101. http://dx.doi.org/10.1037/1040-3590.4.1.92.
Grieve, R, \& de Groot, HT. (2011). Does online psychological test administration facilitate faking? Computers in Human Behavior, 27(6), 2386-2391. http://dx. doi.org/10.1016/j.chb.2011.08.001.

Gustavsson, D. E., Miyake, A., Hewitt, J. K., Friedman, N. P. (in press). Genetic relations among procrastination, impulsivity, and goal-management ability: Implications for the evolutionary origin of procrastination. Psychological Science. doi: http://dx.doi.org/10.1177/0956797614526260

Harriott, JS, \& Ferrari, JR. (1996). Prevalence of procrastination among samples of adults. Psychological Reports, 78, 611-616. http://dx.doi.org/10.2466/ pr0.1996.78.2.611.

Harvey, RJ, Billings, RS, \& Nilan, KJ. (1985). Confirmatory factor analysis of the job diagnostic survey: good news and bad news. Journal of Applied Psychology, 70(3), 461-468. http://dx.doi.org/10.1037/0021-9010.70.3.461.

Hinkin, TR. (1995). A review of scale development practices in the study of organizations. Journal of Management, 21(5), 967-988. doi:10.1016/0149-2063 (95)90050-0.

Holländare, F, Andersson, G, \& Engström, I. (2010). A comparison of psychometric properties between internet and paper versions of two depression instruments (BDI-II and MADRS-S) administered to clinic patients. Journal of Medical Internet Research, 12(5), e49. http://dx.doi.org/10.2196/jmir.1392.

Klingsieck, KB. (2013). Procrastination: when good things don't come to those who wait. European Psychologist, 18(1), 24-34. http://dx.doi.org/10.1027/10169040/a000138.

Krause, J, \& Freund, AM. (2014). Delay or procrastination - a comparison of selfreport and behavioral measures of procrastination and their impact on affective well-being. Personality and Individual Differences, 63, 75-80. http://dx. doi.org/10.1016/j.paid.2014.01.050.

Lay, CH. (1986). At last, my research article on procrastination. Journal of Research in Personality, 20(4), 474-495. http://dx.doi.org/10.1016/0092-6566(86)90127-3.

Lindner, P, Andersson, G, Öst, L-G, \& Carlbring, P. (2013). Validation of the internet-administered quality of life inventory (QOLI) in different psychiatric conditions. Cognitive Behaviour Therapy, 42(4), 315-327. http://dx.doi.org/ 10.1080/16506073.2013.806584.

Luce, KH, Winzelberg, AJ, Das, S, Osborne, MI, Bryson, SW, \& Taylor, B. (2007). Reliability of self-report: paper versus online administration. Computers in Human Behavior, 23, 1384-1389. http://dx.doi.org/10.1016/j.chb.2004.12.008.

Mann, L. (1982). Decision-making questionnaire. Flinders University of South Australia: Unpublished manuscript.

Mann, L, Burnett, P, Radford, M, \& Ford, S. (1997). The Melbourne decision making questionnaire: an instrument for measuring patterns for coping with decisional conflict. Journal of Behavioral Decision Making, 10, 1-19.

Marx, RG, Menezes, A, Horovitz, L, Jones, EC, \& Warren, RF. (2003). A comparison of two time intervals for test-retest reliability of health status instruments. Journal of Clinical Epidemiology, 56(8), 730-735. http://dx.doi.org/10.1016/ S0895-4356(03)00084-2.

McGraw, KO, \& Wong, SP. (1996). Forming inferences about some intraclass correlation coefficients. Psychological Methods, 1, 30-46. http://dx.doi.org/ 10.1037/1082-989X.1.1.30.

McCown, WG, Johnson, JL, \& Petzel, T. (1989). Procrastination, a principal components analysis. Personality and Individual Differences, 10, 197-202. http://dx.doi.org/10.1016/0191-8869(89)90204-3.

O'Donoghue, T, \& Rabin, M. (1999). Incentives for procrastinators. Quarterly Journal of Economics, 114, 769-816. http://dx.doi.org/10.1162/ 003355399556142.

Pychyl, TA, \& Flett, GL. (2012). Procrastination and self-regulatory failure: an introduction to the special issue. Journal of Rational-Emotive \& CognitiveBehavior Therapy, 30, 203-212. http://dx.doi.org/10.1007/s10942-012-0149-5.

Ramo, DE, Rodriguez, TMS, Chavez, K, Sommer, MJ, \& Prochaska, JJ. (2014). Facebook recruitment of young adult smokers for a cessation trial: methods, metrics, and lessons learned. Internet Interventions, 1(2), 58-64. http://dx.doi. org/10.1016/j.invent.2014.05.001.

Rebetez, MML, Rochat, L, Gay, P, \& Van der Linden, M. (2014). Validation of a French version of the Pure Procrastination Scale (PPS). Comprehensive Psychiatry, 55(6), 1442-1447. http://dx.doi.org/10.1016/j. comppsych.2014.04.024.

Rozental, A, \& Carlbring, P. (2013). Internet-based cognitive behavior therapy for procrastination: study protocol for a randomized controlled trial. JMIR Research Protocols, 2(2), e46. http://dx.doi.org/10.2196/resprot.2801.

Rozental, A, Andersson, G, Boettcher, J, Ebert, DD, Cuijpers, P, Knaevelsrud, C, Brjánn Ljótsson, B, Kaldo, V, Titov, N, \& Carlbring, P. (2014). Consensus statement on defining and measuring negative effects of internet 

invent.2014.02.001.

Schmitt, N, \& Stults, DM. (1985). Factors defined by negatively keyed items: The result of careless respondents? Applied Psychological Measurement, 9(4), 367-373. http://dx.doi.org/10.1177/014662168500900405.

Sirios, FM, Melia-Gordon, ML, \& Pychyl, TA. (2003). "I'll look after my health, later": an investigation of procrastination and health. Personality and Individual Differences, 35, 1167-1184. http://dx.doi.org/10.1016/S0191-8869(02)00326-4.

Sirios, FM. (2004). Procrastination and intentions to perform health behaviors: the role of self-efficacy and the considerations of future consequences. Personality and Individual Differences, 37, 115-128. http://dx.doi.org/10.1016/j. paid.2003.08.005.

Sirios, FM. (2007). "I'll look after my health, later": a replication and extension of the procrastination-health model with community-dwelling adults. Personality and Individual Differences, 43, 15-26. http://dx.doi.org/10.1016/j. paid.2006.11.003.

Solomon, LJ, \& Rothblum, ED. (1984). Academic procrastination: frequency and cognitive-behavioral correlates. Journal of Counseling Psychology, 31(4), 503-509. http://dx.doi.org/10.1037/0022-0167.31.4.503.

Specter, MH, \& Ferrari, JR. (2000). Time orientations of procrastinators: focusing on the past, present, or future? Journal of Social Behavior and Personality, 15, 197-202.

Spitzer, RL, Kroenke, K, Williams, JBW, \& Löwe, B. (2006). A brief measure for assessing generalized anxiety disorder: The GAD-7. Archives of Internal Medicine, 166, 1092-1097. http://dx.doi.org/10.1001/archinte.166.10.1092.

Stead, R, Shanahan, MJ, \& Neufeld, RWJ. (2010). "I'Il go to therapy, eventually: procrastination, stress and mental health. Personality and Individual Differences, 49, 175-180. http://dx.doi.org/10.1016/j.paid.2010.03.028.

Steel, P, Brothen, T, \& Wambach, C. (2001). Procrastination and personality, performance, and mood. Personality and Individual Differences, 30, 95-106. http://dx.doi.org/10.1016/S0191-8869(00)00013-1.

Steel, P, \& König, CJ. (2006). Integrating theories of motivation. Academy of Management Review, 31, 889-913. http://dx.doi.org/10.5465/ AMR.2006.22527462

Steel, P. (2007). The nature of procrastination: a meta-analytic and theoretical review of quintessential self-regulatory failure. Psychological Bulletin, 133(1), 65-94. http://dx.doi.org/10.1037/0033-2909.133.1.65.

Steel, P. (2010). Arousal, avoidant and decisional procrastinators: Do they exist? Personality and Individual Differences, 48, 926-934. http://dx.doi.org/10.1016/j. paid.2010.02.025

Steel, P. (2012). The Procrastination Equation. Edinburgh: Pearson Education Ltd.

Svanborg, P, \& Åsberg, M. (2001). A comparison between the Beck Depression Inventory (BDI) and the self-rating version of the Montgomery Åsberg Depression Rating Scale (MADRS). Journal of Affective Disorders, 64(2-3), 203-216. http://dx.doi.org/10.1016/S0165-0327(00)00242-1.

Thorndike, FP, Carlbring, P, Smyth, FL, Magee, J, Gonder-Frederick, L, Öst, L-G, \& Ritterband, LM. (2009). Web-based measurement: effect of completing single or multiple items per webpage. Computers in Human Behaviour, 25, 393-401. http://dx.doi.org/10.1016/j.chb.2008.05.006.

Tice, DM, \& Baumeister, RF. (1997). Longitudinal study of procrastination, performance, stress and, health: the costs and benefits of dawdling. Psychological Science, 8, 454-458. http://dx.doi.org/10.1111/j.1467-9280.1997. tb00460.x.

Weir, JP. (2005). Quantifying test-retest reliability using the intraclass correlation coefficient and the SEM. The Journal of Strength \& Conditioning Research, 19(1), 231-240

Zimmerman, DW. (2007). Correction for attenuation with biased reliability estimates and correlated errors in populations and samples. Educational and Psychological Measurement, 67(6), 920-939. http://dx.doi.org/10.1177/ 0013164406299132.

Zwick, WR, \& Velicer, W,F. (1986). Comparison of five rules for determining the number of components to retain. Psychological Bulletin, 99(3), 432-442. http://dx.doi.org/10.1037/0033-2909.99.3.432.

doi:10.1186/s40359-014-0054-z

Cite this article as: Rozental et al.: Psychometric evaluation of the Swedish version of the pure procrastination scale, the irrational procrastination scale, and the susceptibility to temptation scale in a clinical population. BMC Psychology 2014 2:54.

\section{Submit your next manuscript to BioMed Central and take full advantage of:}

- Convenient online submission

- Thorough peer review

- No space constraints or color figure charges

- Immediate publication on acceptance

- Inclusion in PubMed, CAS, Scopus and Google Scholar

- Research which is freely available for redistribution

Submit your manuscript at www.biomedcentral.com/submit 